\title{
Issues and Challenges in Open and Distance e-Learning: Perspectives from the Philippines
}

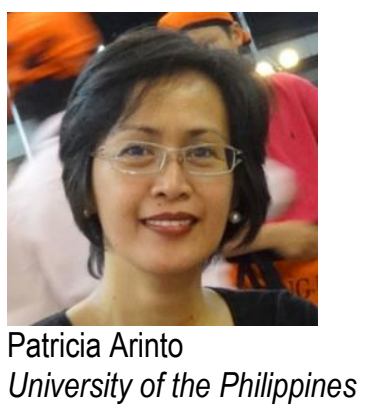

\begin{abstract}
Rapid advances in information and communications technology in the digital age have brought about significant changes in the practice of distance education (DE) worldwide. DE practitioners in the Philippines' open university have coined the term 'open and distance e-learning' (ODeL) to refer to the new forms of DE, which are characterised by the convergence of an open learning philosophy, DE pedagogies, and e-learning technologies. This paper discusses the issues and challenges that ODeL poses for the Philippines' open university from the point of view of the institution's leading ODeL practitioners. The paper concludes with a discussion of the policy development and administrative changes required to support innovative teaching practice across the institution. The findings and conclusions are relevant for other institutions in the same stage of ODeL development.
\end{abstract}

Keywords: distance education, online learning, e-learning, open and distance e-learning

\section{Introduction}

Rapid advances in information and communications technology (ICT) have brought about significant changes in the field of distance education (DE) since the mid-1990s. These are encapsulated in the shift by many DE institutions from print-based to online delivery using virtual learning environments (VLEs) and various Web technologies. This has so altered the organisation, practices, and cultures of DE (Abrioux, 2001; Bennett, Agostinho, Lockyer \& Harper, 2009; Cleveland-Innes, 2010) that DE scholars have characterised it as a generational shift (see, for example, Taylor, 2001). 
At the University of the Philippines - Open University (UPOU), a single-mode DE institution in the Philippines, the term "open and distance e-learning" (ODeL) has been coined to refer to the new mode of online or Web-based DE. More specifically, ODeL refers to "forms of education provision that use contemporary technologies to enable varied combinations of synchronous and asynchronous communication among learners and educators who are physically separated from one another for part or all of the educational experience" (Alfonso, 2012, n.p.). ODeL expands the term "open and distance learning" or ODL to include use of e-learning or online learning methodologies to enable multiple forms of interaction and dialogue that can bridge the distance between teachers and learners (Anderson, 2008c; Calvert, 2005; Garrison, 2009) and provide access to a vast array of interactive and multimedia learning resources that can be used to design learning environments for learners in diverse circumstances (Bates, 2008; Haughey, Evans \& Murphy, 2008; Tait, 2010). Using online portals and VLEs further enables DE institutions to support both independent learning and collaborative learning through “increasingly complex pedagogical structures" (Haughey et al., 2008, p. 15).

Indeed, 21st century DE is distinguished from older forms of DE by flexibility and adaptability of design (Garrison, 2000; Haughey et al., 2008; Tait, 2010). While industrial era DE deployed "standardised, normalised and formalised procedures for design and delivery" (Peters, as cited in Burge \& Polec, 2008, p. 238), in online DE the boundary between course development and course delivery is increasingly blurred and "former course development roles . . . are being deconstructed and reinvented" (Abrioux, 2001, p. 1) as the role of teachers in the design of pedagogically effective learning environments receives renewed emphasis (Anderson, 2008c; Bennett et al., 2009). Moreover, DE course designs are increasingly "resource-based" (Calvert, 2005; Naidu, 2007), and in some cases, "online discussion-based" (Jara \& Fitri, 2007), with course contents that are "more fluid and dynamic" because they are created during synchronous and asynchronous online collaborative activities (Mason, 1998).

These pedagogical changes in DE underscore the fact that online technologies are not neutral: they are like "a 'trojan mouse' that teachers let into their practice without realizing that it will require them to rethink not just how they use particular hardware or software, but all of what they do" (Sharpe \& Oliver, 2007, p. 49). Furthermore, pedagogical change is complex and often challenging not only for individual teachers but also for the DE institution as a whole. As Abrioux (2001) has noted, the enhancement of "old models of distance education by taking advantage of the e-learning environment" is just as challenging as the adoption of online learning by conventional institutions because "the [very same] institutional infrastructures and learning/teaching support functions... which, in the past, complemented the individual academic's expertise and served to create a comprehensive high quality learning environment for distance learners" (p. 1) might also now constrain innovative practice by distance educators. ${ }^{1}$

This paper discusses key issues and challenges in ODeL implementation as experienced and perceived by 10 academics at UPOU, and their implications for institutional policy and practice. UPOU exemplifies Abrioux's (2006b) "university within a university" model, an institutional arrangement designed

\footnotetext{
${ }^{1}$ The "constraining infrastructure" includes "capital investments such as printing presses, television and radio production, course material warehouses, and various administrative and computing systems" and "institutional investments in human resources ... and labor relations structures" (Abrioux, 2001, p. 1).
} 
to "protect the ODL culture in a dual-mode institution" (p. 5). One of seven universities and an autonomous college comprising the University of the Philippines (UP) system, UPOU was established in 1995 to democratise access to quality higher education through DE. It offers three undergraduate programmes, 24 graduate programmes, and two doctoral programmes in what Becher (1989) calls "soft applied" disciplines. ${ }^{2}$ Majority of its students are Filipino citizens between 20 and 40 years old (Flor, Bandalaria, Sibal \& Jarmin, 2008) with full- or part-time employment. About 80\% are based in the Philippines and the rest live and work abroad. 3 The faculty complement consists of 26 full-time faculty members and about 200 faculty affiliates who teach part-time at UPOU. The small complement of full-time faculty is part of a strategy adopted by UPOU's founders to forestall doubts about the quality of $\mathrm{DE}$, which is perceived by some to be inferior to face-to-face teaching, by having the faculty of the more established units develop and deliver most of UPOU's courses (Arinto, 2007).

UPOU started out with a print-based mode of course development and delivery. In 2000 it introduced online tutorials using an open source learning management system (LMS) initially for students who were unable to attend the monthly face-to-face tutorial sessions. As students became more widely dispersed geographically and as the Internet became more accessible to teachers and students alike, online tutorials became the default tutorial mode for all courses, and in 2007 UPOU shifted to a Moodle-based online learning platform. Aside from an increased emphasis on resource-based course design, this also marked a shift to the development of new courses via "a reduced version ... of the course team approach" (Power, 2007, p. 65) where individual faculty members both design and deliver the courses asynchronously online. In addition to the Moodle VLE, some of UPOU's full-time faculty create course blog sites and use Web-based conferencing systems and social networking services. While the old printed course modules have not been phased out, course instructors are expected to update the modules by supplementing them with relevant resources and by introducing new learning activities and assignments.

In sum, the DE model at UPOU is one where students: (a) engage in guided independent study of mostly text-based course packages; (b) participate in computer-mediated discussion and collaborative learning activities conducted asynchronously through a Moodle-based VLE; (c) submit assignments; and (d) for most courses, sit for a proctored final examination at a UPOU learning centre or testing centre. ${ }^{4}$ UPOU is not entirely unique as a DE institution and this case study of the ODeL issues and challenges that UPOU is confronting in today's rapidly changing DE context should provide insights that would be relevant for similarly situated DE institutions.

\footnotetext{
2 UPOU offers programmes in such disciplines as environmental management, development communication, and public administration. The full list of programme offerings is available at http://www2.upou.edu.ph/academic-programs.

3 The offshore students, as the non-Philippine-based students are called, are dispersed in more than 40 locations worldwide, including the United States, United Arab Emirates, China, Hong Kong, Japan, Korea, and many other countries where there are overseas Filipino workers.
}

4 Some FICs administer online examinations using the quiz feature on Moodle or via email. 


\section{Methodology}

This paper reports part of the findings of a collective case study of ODeL course design practice in a $\mathrm{DE}$ institution based on the experiences of 10 university faculty. A collective case study is derived from joint analysis of several individual cases (Stake, 1995) to help provide a general understanding of a phenomenon that extends beyond single unique cases (Harling, 2002). The generalisation aimed for is analytic generalization, which is defined as "the development of a theory which helps in understanding other cases or situations" (Robson, 2002, p. 177).

The 10 research participants were purposively selected based on two criteria: (1) they use various Web technologies in their courses, and they use these technologies in a variety of ways; and (2) their collective experience of DE at UPOU spans several "generations," from the early phase of pre-packaged print-based materials with face-to-face tutorials, to the middle phase of print-based materials with online tutorials, to the more recent phase of resource-based online course development and delivery. Eight full-time UPOU faculty and two affiliate faculty administrators who have been closely involved with the institution since its establishment were thus selected as research participants. Three of them are male and seven are female, reflecting the predominance of female faculty members in the university as a whole. Three are assistant professors, four are associate professors, and three are full professors. Four have at least 10 years of experience in teaching at a distance, two have more than five years experience, and four have less than five years experience. Each professor teaches courses from different disciplines, all teach graduate level courses, and four teach undergraduate level courses as well. In addition, all 10 are faculty administrators and/or have administrative roles, which gives them a vantage point from which to observe the course design practice of other faculty members and reflect on the factors that impact on this practice, the issues arising therefrom, and their implications for policy and operations.

Data were collected through semi-structured interviews lasting 45 to 90 minutes each. The interviews sought to elicit the pedagogical rationale for the research participants' use of Web technologies in their courses, their perspectives on the impact of teaching with the Web on their course design practices, and their views on personal as well as more macro or institution-wide issues and challenges in online course design. The interview data were analysed "horizontally" or "cross-sectionally" (i.e., for each theme and sub-theme, data from all research participants were examined and patterns identified and analysed). These patterns were then compared and contrasted with related patterns or themes in the theoretical and empirical literature on the impact of technology integration on pedagogy and key issues and challenges in online learning design especially in DE contexts. These related themes are presented briefly in the next section.

\section{Conceptual Framework}

Two trends are noted in the literature on the impact of technology integration on pedagogical practice. The first is that contrary to expectations, teaching approaches in e-learning contexts are not necessarily being transformed or changed for the better (Conole, 2004; Hedberg, 2006; Kirkwood, 2009; Natriello, 2005). Instead, there is a persistence of traditional modes of teaching and, in some cases, outright resistance to educational innovation. In a study of VLE use by faculty in a university in Ireland, 
Blin \& Munro (2008) found that the dominant use of the VLE was for the dissemination of courserelated materials previously distributed via the Intranet or on paper (see also Sharpe et al., 2006). Hedberg (2006) cites survey results indicating that for majority of more than 20,000 students and 800 staff surveyed in five large technological universities in Australia, online learning meant the provision of information online and unmoderated discussions. Kirkwood (2009) observes that "Despite huge investment in infrastructure by governments and individual institutions, there ... [are] disappointing levels of uptake, of engagement, [and] limited development of 'learning communities"' in both campus-based blended learning and DE contexts (p. 109).

The mix of factors accounting for non-transformational use of technologies differs according to context (Kirkwood, 2009). But one factor that might be true in most if not all contexts is faculty preparedness for the complex and challenging practice of design for effective learning with technology. eLearning design requires the integration of diverse knowledge systems, which is not a simple or straightforward process. In Markauskaite \& Goodyear's (2009) study of one university teacher in Australia "to discover how different mental resources are activated and blended in making complex professional judgments about learning design, teaching and inquiry in specific contexts" (p. 617), they found evidence of the need for and the complexity "of integrating pedagogical frames and ICT tools with the other knowledge frames needed to design productive learning tasks" (p. 621) for teaching specific disciplinary knowledge. Siemens (2007) has referred to the curatorial role of teachers in networked learning, which requires expertise in the subject matter to be able to select, annotate, and showcase resources to enable the learners who explore them to engage with the subject matter and develop an understanding of the key concepts of the discipline. At the same time, "[the] curatorial teacher acknowledges the autonomy of learners" so that "[i]nstead of dispensing knowledge, he creates spaces in which knowledge can be created, explored, and connected" and learners' "freedom to explore is unbounded" (Siemens, 2007, n.p.).

The second trend noted in the literature on how technology impacts teaching practice is the shift from a teacher-focused knowledge transmission approach to a learner-focused knowledge generation approach (Armellini \& Jones, 2008; Swan, 2010). This shift however does not occur automatically. As Burge \& Polec (2008) have pointed out, "some educators, coming from transmission modes of teaching face-to-face in conventional higher education, realise after some online trials that they may need some new teaching models, but others may see online as a new vehicle for transmitting pre-digested information" (p. 246). Furthermore, while a shift from transmission models of teaching to constructivist learning models might be assumed from teachers' use of interactive features of online software, "many solo course designers have to struggle their way into the new model" (p. 249).

Indeed, changing teachers' pedagogical orientations and approaches requires a broadening of the teachers' awareness of the pedagogic opportunities afforded by learning technologies and the development of their knowledge and skills in online learning design through a professional development programme that fosters critical reflection on technology use in teaching and learning (Hughes, 2004; Daly \& Pachler, 2007). In addition, such programmes should be holistic and address a complex of factors such as the following: the policy environment (Conole, 2007; Pachler \& Daly, 2011); institutional support for technology integration (Kirkwood, 2009; Sharpe, Benfield \& Francis, 2006); a vision for technology-supported teaching and learning (Bates, 2000; Hughes, 2004); teachers' personal and professional use of technology (Becker, 2000; Russell, Bebell, O’Dwyer \& O'Connor, 2003); teachers' pedagogic orientation and subject subculture (John, 2005; John and La Velle, 2004); and member- 
ship in a community of practice (John, 2005; Laurillard, 2011; Otero, Peressini, Meymaris, Ford, Garvin, Harlow, Reidel, Waite \& Mears, 2005).

Kirkwood \& Price (2006) argue for professional development that includes not only the individual teacher but also departmental faculty and senior university managers in order to "help engender an evidence-based and genuinely developmental approach" to e-learning policy development within higher education institutions (p. 10). Policy development needs to address policy gaps as well as "policy tensions" (Hardy, 2008; Pachler \& Daly, 2011) or conflicting policy pressures arising from incompatible or contradictory policies, procedures, and guidelines, "whether ratified or tacitly agreed" (Masterman \& Vogel, 2007, p. 58). For example, there can be tensions between policy on assessment of student learning and policy promoting innovation with ICT (Pearson \& Naylor, 2006) as well as contradictory discourses within policies promoting innovation that, when coupled with pressure to rapidly implement a complex learning reform agenda, can militate against policy support for good practice in professional development in e-learning (Hardy, 2008). Among established DE universities, there is a need to review and reconceptualise organisational structures and procedures in order to manage and support innovations, and to address issues such as service standards for students and staff, and quality assurance (Abrioux, 2001, 2006a \& 2006b; Annand, 2007; Sangra, 2006).

The foregoing are the key issues and challenges for pedagogical practice posed by the integration of online technologies. In the next section, issues and challenges in ODeL from the point of view of the 10 academics included in this study are presented and analysed.

\section{Findings and Discussion: Issues and Challenges in ODeL}

In general, the issues and challenges identified by the research participants may be classified into two: (1) the need to stimulate innovative practice among UPOU faculty who remain unengaged in ODeL; and (2) the need to support and sustain innovative practice among the innovators (Table 1). 
Table 1

Issues and Challenges in ODeL Practice at UPOU

\begin{tabular}{|l|l|}
\hline How to stimulate innovation? & How to sustain innovation? \\
\hline $\begin{array}{l}\text { New demands on educational institutions } \\
\text { and faculty to adopt innovative practices (P10, } \\
\text { P7) }\end{array}$ & $\begin{array}{l}\text { Need for resources } \\
\text { - time to engage in design work (P4, P5, P7) } \\
\text { - appropriate tools (P1) }\end{array}$ \\
$\begin{array}{l}\text { Need to address faculty indifference (P5, P6) } \\
\text { and resistance (P3) resulting from }\end{array}$ & $\begin{array}{l}\text { Need for guidance and technical support } \\
\text { - lack of time (P3) }\end{array}$ \\
- the difficulty of ODeL (P3) \\
- the need for pedagogical reorientation (P3, P5) & - - - students as co-creators (P2) \\
Need for training and models (P3) & $\begin{array}{l}\text { Need for community } \\
\text { - for sharing good practices (P2) }\end{array}$ \\
Need to address political considerations (P6) & - building a network of experts (P3) \\
& Need for quality standards (P1, P4, P6) \\
\hline
\end{tabular}

(Note: The research participant who mentioned a particular issue is referred to by the notation $\mathrm{P}$ and a number. For example, P1 refers to the first research participant and $\mathrm{P}_{3}$ refers to the third research participant.)

While the problem of faculty indifference and resistance to technology integration is fairly common, there are nuances to how this issue plays out at UPOU that may be unique to this context. First, those who were described as unengaged in innovative practice are mostly affiliate faculty or faculty of other UP units who teach part-time at UPOU. Some research participants (notably $\mathrm{P}_{3}, \mathrm{P}_{5}$, and P6) referred to this group's seeming inability to face up to the demands of online distance teaching in spite of exposure to training in ODeL through UPOU-organised workshops and seminars. $\mathrm{P}_{3}$ and $\mathrm{P}_{5}$ ascribed this to the fact that ODeL requires not only the acquisition of technology-related skills but also a pedagogical re-orientation, which many academics would find challenging. As P9 pointed out, faculty members are selected to teach courses on the basis of their expertise in the subject matter, and they do not necessarily have knowledge of appropriate and effective pedagogy especially for online learning contexts. Thus they need to (re)examine how they teach, and be open to alternative ways of teaching:

The pedagogy in DE is very different from that in face-to-face teaching. And I think until now we haven't really succeeded in bringing about this shift in the mindset of our affiliate faculty. Until now, for them it's still using the computer, using email to address the concerns of the students as if they're in face-to-face setting. They do not know how to design learning activities meant for distance learners. $\left(\mathrm{P}_{3}\right)$

Because distance education is mediated by course materials in different forms, the challenge I think is in the teacher understanding such mediation and then using media as an agent, the teacher's agent, to accomplish teaching. ... They tend to blame the university for not providing them training. Yeah, that's one thing and I think that's real. But ... I think you need to 
understand the nature of that work, to come to terms with yourself, to surface your own understanding of what teaching is. $\left(\mathrm{P}_{5}\right)$

$\mathrm{P}_{3}$ and $\mathrm{P}_{5}$ 's remarks also suggest that the training in ODeL that faculty members get may be inadequate. P8 in this study mentioned "no proper orientation" as a problem that she experienced as a new faculty member. This raises the question of how much and what kind of orientation and training is required to foster the pedagogical re-orientation that $\mathrm{P}_{3}$ and $\mathrm{P}_{5}$ describe. It would seem that faculty members need to devote time not only to participating in a training programme but also to exploration and experimentation and learning from practice. However, many affiliate faculty are not able to make this time investment in teaching online (as noted by $\mathrm{P}_{3}, \mathrm{P}_{5}$, and $\mathrm{P}_{7}$ ). They have other priorities, such as their teaching and research work in their home units. Furthermore, teaching online is not easy, as $\mathrm{P}_{3}$ pointed out: "I think the resistance is really because it's really difficult, it's not easy to teach in the distance learning environment" (cf. Collis \& Moonen, 2008).

The problem is that UPOU continues to rely on affiliate faculty to teach a significant number of its course offerings every term. Although there has been a gradual realisation that UPOU needs a bigger complement of full-time faculty than its founders had anticipated, getting additional full-time faculty is challenging. For one, the creation of additional faculty positions needs the approval of the UP System and the Philippine Government, and this approval hinges on budgetary considerations. Second, it is difficult to recruit faculty with the knowledge, skills, and disposition for teaching at a distance, as proven by recent faculty recruitment efforts.

Given UPOU's dependence on affiliate faculty for course delivery, engaging the affiliate faculty is a political issue as much as it is an administrative challenge, as P6 pointed out:

... who do you give the course to? And then I think about the politics. . . . in particular, we should be sensitive to the fact that we have two tracks.... If one day the College of XXX decides that they will no longer participate, a whole track [would disappear]! They [the College faculty] distribute the teaching assignments among themselves. They have a say in these matters. I am trying to proactively maintain a relationship with them or else one day we will just be surprised that they have decided to stop [teaching with us].... (P6)

Indeed, breakdowns in relationships with affiliate faculty members can result in the suspension of an entire programme, as has happened in the case of two UPOU programmes. This is one of the vulnerabilities of small and medium-sized DE institutions that are dependent on the academic collaboration of campus-based sister institutions for developing and implementing their courses and programmes (Abrioux, 2006b).

Alongside issues related to lack of innovation are issues regarding how to support those who are innovating. The need for resources, guidance, and community-what Laurillard (2008) refers to as "mechanisms for innovation in teaching and learning" (p. 529)-were specified. Two resources in particular were mentioned: time and tools. Lack of time for design work was cited by at least three faculty members ( $\mathrm{P}_{4}, \mathrm{P}_{5}$, and $\mathrm{P}_{7}$ ). As $\mathrm{P}_{5}$ noted, this may well be unique to the "particular context of UPOU," where the full-time faculty are "very much active in the administration of the university". Nevertheless, few would dispute that design is "creative work and it requires reflection ... [and] quiet time" ( $\mathrm{P}_{5}$ ) without which even teachers who are willing to innovate end up replicating old practices (P8). Equally important are the right tools for facilitating course design. P1, for example, referred to the need to have 
access to "data from previous courses offerings" to avoid having "to start from scratch to develop your course site and to design your course."

Academics also need technical support and guidance especially when implementing a new pedagogy. For example, as P1 stated, "before you can design your course, you need information about the learners because course design may become a constraint to some students if you do not consider their profile, their background" (cf. Naidu, 2007).

At present, giving faculty members the profile of learners enrolled in a course is not done consistently across all programmes and for all courses at UPOU. 5 Also, some programmes have very large enrolments and the enrolment profile that is drawn up covers only basic data like age, sex, domicile, educational attainment, and occupation.

But knowing the profile of learners is not enough. Beetham (2007) notes two challenges in adopting a learner-centred approach to design: knowing which learner differences matter in a particular learning context, and addressing learner differences appropriately and effectively. In this study, P8 alludes to these two challenges thus: “... the diverse backgrounds of students, the age gaps, are crazy. ... There are students, classmates, who are father and son.... [Y] ou really have to design [different] materials for these [diverse] groups.” P8 has expressed an interest in researching and developing adaptive learning systems for UPOU. Adaptive learning is one of two approaches to learner-centred design mentioned by Beetham. The other is providing for flexible learning. However, there seems to be little practical engagement with flexible learning among the research participants and this is clearly an area in which they need further development.

The faculty also need guidance on how to "operationalise" the concept of learners as co-creators (P2) or what Collis \& Moonen (2008) refer to as "contribution-oriented pedagogies" where "the learner is involved in the contribution of at least some of the learning resources in a course or even in the design of some aspects of the course as he or she participates in it” (p. 98). In this study, P2 articulates this challenge thus:

One challenge has to do with ... our students as co-creators ... I want to experiment on how the inputs of the students can be used as text . . . for the current course. All of the text produced, all of the knowledge [created] in my previous course should input into the next one. (P2)

P2 is an example of a teacher at the "invention stage," the most advanced of five stages of "instructional evolution" in technology use (Sandholtz et al., 1997). Teachers at this stage experiment with different technology-supported instructional practices, including new ways of relating to students and colleagues. To get to this stage, teachers need formal instruction in technology use, opportunities for experimentation and critical reflection on practice, and active participation in a community of practice (Hughes, 2004; Jacobsen et al., 2002). Membership in a community of practice gives faculty members

\footnotetext{
5 While faculty members who will be handling a course for the first time might be given a general orientation to a programme, including the background of learners, faculty members who have taught in the programme previously might not get this kind of orientation for specific courses.
} 
the opportunity to share good practices and learn from each other (as P2 explained), and it provides an opportunity for teachers "to participate in new ways of thinking-or counter-thinking-in order to act according to critically informed understandings of teaching and learning" (Daly \& Pachler, 2007, p. 55). However, building a community of practice is not easy. For UPOU's full-time faculty, being geographically dispersed and having multiple responsibilities (administrative work on top of teaching and research6-an issue alluded to by $\mathrm{P}_{4}, \mathrm{P}_{5}$, and $\mathrm{P}_{7}$ ) are barriers to regular formal exchanges and informal conversations about teaching and learning. A possible solution to this problem and to not having enough full-time faculty may be derived from P3's suggestion of a network-based approach to teaching a course:

... [but] we have to look for networks that we can partner with or collaborate with ... because there are only a few full-time faculty and obviously we don't have [all of the necessary expertise]. It will be very good if we can explore networks that we can collaborate with as a university. And that would strengthen the potential of coming up with resource-based learning. Because even if we say it's resource-based learning, we cannot assume that the students will only interact with the materials. A lot of it also has something to do with experts facilitating. ( $\left.\mathrm{P}_{3}\right)$

$\mathrm{P}_{3}$ is referring specifically to extending current teaching arrangements to include experts external to UPOU. But her use of the term "network" also suggests the idea of an online community of practice for both full-time and part-time UPOU faculty.

While there are issues and challenges that are specific to particular groups of faculty, how to assure the quality of course design and teaching in ODeL, an issue raised by P1, P4, and P6 and implied by other research participants, confronts the faculty and institution as a whole. As P4 noted, this is an offshoot of the shift from a standardised model of DE to more ad hoc and fluid DE models enabled by the availability of various technologies:

I think right now the problem with online teaching and learning as a mode of teaching is that there are too many opportunities, there are too many options, there are too many ways of doing things such that our faculty members and course authors are confused!... we're all experimenting, grappling with all the techniques, and improvising. I think there will come a time when all of these things will settle. But right now we're in that stage of to each his own. I think that comes with new approaches and new technology and that's part of the excitement. But-

...I think the issue is about quality. How do we make sure that the students get the kind of education that they deserve and... paid for? At the same time, we also want to ensure, as much as possible, some sort of a uniform learning experience.... I think there has to be some sort of a common learning experience across programmes. Of course you have different ways of teaching depending on the discipline, but- $\left(\mathrm{P}_{4}\right)$

P6 suggested laying down minimum requirements for all course instructors:

6 UPOU has two main offices: one in Los Banos, Laguna (the headquarters) and the other in Diliman, Quezon City. It takes 2-2.5 hours travel by car to get from one to the other location. 
... there could be minimum standards, right? Like at least fix your course site. The materials that need to be updated I think we are able to address. We do have a system for giving incentives to do that, right? You can get credit for doing that; you can get paid if you are an adjunct faculty member.... (P6)

These remarks suggest a "carrot-and-stick" approach to assuring quality, which has limitations, as P6 himself admits. Davis (2001, p. 7) notes, "Academics, being essentially creative people, prefer to devise and explore their own approaches to anything, and resent being told how their courses and programs shall be delivered." A regulatory approach also does not take into account ambiguities and tensions that faculty members experience in rapidly changing teaching and learning contexts (Davis, 2001; Hardy, 2008). In this study, P10 alluded to this issue thus:

....But at the same time, especially people who are affiliate [faculty], they're used to the traditional mode of teaching which is the classroom. And then they were taught how to write modules and to teach using the modules. They got this idea that the module is the teacher and that they don't really have to engage with the students that much. And then here comes online learning which says, hey, you have opportunities for interactivity again but you have to do it in a different way-asynchronously. So I can just imagine the adjustments that these people have to undergo along the process. (P10)

The rapid pace of change can be confusing even for the full-time faculty, as P1 noted:

I am looking for some standard that would give us our identity as a DE institution. Right now, we have different ways of dealing with our classes and courses. In the past I didn't even know if what I was doing counted as DE or whether it qualifies as DE pedagogy. Then I realised from discussions with other faculty members that I'm on the right track. But it would be good to have [a standard] on which you can anchor your practice. (P1)

Like $\mathrm{P}_{4}$ and $\mathrm{P}_{3}$ (who suggested providing models) $\mathrm{P}_{1}$ is referring to a guide for good practice and, more generally, "a common framework for assessing the effectiveness of any. . . approach . . and to draw useful conclusions for future development” (Davis, 2001, p. 13).

To summarise this section, the faculty described what for them are the macro issues and challenges in ODeL course design that UPOU's administrators should address. These include resistance to innovation, uneven innovation practice, and lack of standards for innovation. While similar issues and challenges are described in the literature, the way they play out at UPOU is unique to the institutional context, and the solutions suggested by the faculty have certain nuances. In general, the range of issues and challenges described calls for a holistic approach that includes a coherent framework, relevant policies and guidelines, and appropriate tools and resources for practitioners. This is discussed further in the concluding section of this paper.

\section{Concluding Discussion}


Among the UPOU faculty and administrators included in this study, there is no lack of interest in and willingness to explore new practices and new directions in ODeL. But they admit that they constitute a minority, and they cite as a continuing challenge how to foster innovative teaching and learning practice across the institution as a whole. This is reminiscent of Collis \& van der Wende's (2002) characterisation of higher education institutions "now transferring from a period of rich and mostly bottomup experimentation to a phase in which institution-wide use of ICT is being encouraged" (p. 8). Such institutions go through three stages of ICT implementation: (a) "the establishment of institution-wide technological infrastructure," (b) "rich pedagogical use of this infrastructure," and (c) "strategic use of ICT with a view to the different target groups of higher education" (p. 8). While many institutions are likely to have completed the first stage, the second stage "is in many cases still in development" and the third stage "has in most cases not been considered explicitly yet" (p. 8). This appears to be the case with UPOU. The study's findings have implications for academic developers and administrators at UPOU, particularly with regard to the design of faculty development programmes, provision of faculty support, and strategic planning for ODeL implementation across the institution.

First, training programmes for faculty should aim to develop a comprehensive range of ODeL skills in a systematic and coherent way. Teaching online effectively requires more than technology-related skills (e.g., how to use Moodle). Faculty need skills in content development, learning activities, teaching strategies, and assessment. The development of these skills should be undertaken in such a way that the integration of content, pedagogical, and technological knowledge and skills-that is what Mishra \& Koehler (2006) refer to as technological pedagogical content knowledge or TPACK-is facilitated. (See Arinto [2013] for an ODeL skills framework that addresses this requirement.)

The second implication for practice that may be drawn from the study's findings is that a training programme is not sufficient for practitioner development in ODeL. It is clear from the research participants' descriptions of how their course design practice has evolved that professional development in ODeL is a complex process requiring "exposure to a range of models of technology use" to develop the "understanding [of] differences in interaction with technology and how this affects learning [which] is crucial to designing effective activities, content and learning goals" (Price \& Oliver, 2007, p. 25); continuous engagement in design work; critical reflection; and participation in a community of practice. Thus, course design and other workshops should be part of a holistic academic development programme in ODeL that would include workshops, opportunities for individual and collaborative experimentation, and sharing of experiences and innovations using various tools and resources and with the appropriate technical support.

For UPOU, adopting these mechanisms would require policy and administrative changes, some of which might prove to be particularly challenging. More specifically, to support innovative teaching practice across the institution, this study's findings suggest a need for the following, among others: (a) a significant expansion of the pool of full-time faculty to allow for a re-distribution of administrative workloads to free individual faculty members for course design work; (b) the establishment of a unit that would implement the professional development programme described above; and (c) a reconceptualisation of support structures and services for course development and delivery which at present remain oriented towards a print-based mode of delivery.

Even if it maintains the current policy of having affiliate faculty handle a good percentage of its courses, UPOU needs additional full-time faculty members given the very small number of full-time faculty 
at present and the large number of programme offerings (relative to UPOU's size). As for working with faculty from other UP units, some thought needs to be given to how the affiliate faculty can be better motivated and equipped to engage in ODeL, not just for political reasons (i.e., UPOU needs to maintain collaborative arrangements with other UP units for as long it wishes to remain part of the UP System) but, more importantly, for pedagogical reasons. That is, UPOU should be concerned about ensuring that all of the faculty, whether full-time or part-time, can teach online and at a distance effectively and well. It is true that engaging part-time faculty can be challenging (as some of the research participants have noted), but this might be addressed by a more comprehensive and innovative approach to faculty development.

In general, UPOU's leaders need to recognise the need for strategic policy development and organisational restructuring for ODeL to be effectively implemented. Collis \& van der Wende (2002) note that "Policies are crucial for institutions ... to define what will be their next stage of development ... and how to get there" (p. 66). They recommend in particular that a university intending to implement elearning "should develop a strategic plan relating to the relative importance to the institution of ... different types of learners" (p. 66) and "profile itself around several instructional alternatives and develop pedagogical models and templates for its course management system that support those models" with an eye towards "efficiencies and scalability" (p. 72). Which pedagogical profiles in ODeL should UPOU explore, and how should it "optimise flexible delivery of these profiles" (Collis \& van der Wende, p. 72)? The following questions, which are adapted from Bates (2000), may be used as a guide in the strategic planning required for these bigger questions to be addressed:

- On which target group(s) should UPOU be focused (e.g., high school graduates, working adults, lifelong learners, overseas Filipino workers)?

- How should the mix of ODeL approaches vary, depending on the target group?

- For which teaching and learning goals should asynchronous and synchronous strategies be used?

- Which particular technologies are needed?

- How should faculty be supported?

As for organisational restructuring, this is needed because as Annand (2007) reminds us that

"organizational issues rather than learning theory significantly determine practice. Underlying beliefs about the relative importance of learner autonomy versus social interaction in the learning process are largely informed by adult educators' experiences within particular organizational structures" (p. 1).

At UPOU this is apparent in the largely uncritical adoption of the paced cohort-based model of OdeL. This model is not only based on the "classroom-based learning [that] predominates in universities" but also "easier to support within the processes of the organisation" (Annand, p. 1), including, amongst other things, the semestral system, staffing patterns, and course scheduling schemes. If new pedagogical models are to be adopted, then it is necessary to put in place organisational arrangements that would support each of these models. For innovative practice to gain traction, "the commitment of 
some dedicated individuals will not suffice" and "the institution itself must make a commitment (i.e., for support, resources and personnel) and ... develop a targeted implementation strategy" (Collis \& van der Wende, 2002, p. 10). In implementing flexible learning, for example, there is a need for a system-wide "technological architecture, tools and functionalities" such as "a database driven system that allows easy tailoring and adapting of (portions of) courses to serve the needs of different groups of students" (Collis \& van der Wende, 2002, p. 8).

Finally, with regard to the question of which pedagogical profiles UPOU should adapt and implement, while some profiles might be drawn from the findings of this study, perhaps the more critical point that should be emphasized (also based on the findings of this study) is the need for a plurality of pedagogical models based on an understanding of pedagogical priorities. The increasing diversity of distance learners coupled with the availability of various technologies suggest that UPOU should support several well articulated ODeL models, including hybrid approaches that would allow for flexible learning that balances to some extent, or at least takes into account, the sometimes conflicting interests of accessibility, instructional quality, and cost-effectiveness (Daniel, Kanwar \& Uvalic-Trumbic, 2009; Kanuka \& Brooks, 2010; Power \& Gould-Morven, 2011).

\section{References}

Abrioux, D. (2006a). Athabasca University, Canada: An evolution of an existing institution. In S. D’Antoni (Ed.), The virtual university: Models and messages; Lessons from case studies. Paris, France: UNESCO publishing. Retrieved from http://www.unesco.org/iiep/virtualuniversity/media/document/Ch9_Athabasca_Abrioux.pd $\mathrm{f}$

Abrioux, D. (2006b). Strategic issues in single- and dual-mode distance education: The organizational blending of two Canadian distance universities. Vancouver, Canada: Commonwealth of Learning. Retrieved from http://oasis.col.org/handle/11599/237

Abrioux, D. (2001). Converting to online course and program delivery: Global perspectives [Guest Editorial]. International Review of Research in Open and Distributed Learning, 1(2). Retrieved from http://www.irrodl.org/index.php/irrodl/issue/view/10

Alfonso, G. J. (2012, August). UP Open University: Thoughts about openness in a digitized world [Powerpoint slides]. Presentation at the UPOU Roundtable Discussion, UPOU Oblation Hall, Los Banos, Laguna.

Anderson, T. (2008a). Towards a theory of online learning. In T. Anderson (Ed.). The theory and practice of online learning (2nd ed.; pp. 45-74). Alberta, Canada: Athabasca University Press.

Anderson, T. (2008b). Social software to support distance education learners. In T. Anderson (Ed.), The Theory and Practice of online learning (2nd ed; pp. 221-241). Alberta, Canada: Athabasca University Press. 
Anderson, T. (2008c). Teaching in an online learning context. In Anderson, T. (Ed.), The theory and practice of online learning ( ${ }^{\text {nd }}$ ed; pp. 343-365). Alberta, Canada: Athabasca University Press.

Anderson, T. (2008d). Social software technologies in distance education: Maximizing learning freedoms. In T. Evans; M. Haughey \& D. Murphy (Eds.), International handbook of distance education (pp.167-184). Bingley, UK: Emerald Group Publishing Ltd.

Anderson, T. \& Dron, J. (2011). Three generations of distance education pedagogy. International Review of Research in Open and Distributed Learning 12(3): 80-97. Retrieved from http://www.irrodl.org/index.php/irrodl/article/view/890/1826.

Annand, D. (2007). Re-organizing Universities for the Information Age. International Review of Research in Open and Distributed Learning, 8(3). Retrieved from http://www.irrodl.org/index.php/irrodl/article/view/372/956

Arinto, P. B. (2013). A framework for developing competencies in open and distance e-learning. International Review of Research in Open and Distributed Learning, 14(1). Retrieved from http://www.irrodl.org/index.php/irrodl/article/view/1393

Arinto, P. (2007). Going the distance: Towards a new professionalism for full-time distance education faculty at the University of the Philippines. International Review of Research in Open and Distributed Learning, 8(3). Retrieved from http://www.irrodl.org/index.php/irrodl/article/view/409/941

Armellini, A. \& Jones, S. (2008). Carpe Diem: seizing each day to foster change in e-learning design. Reflecting Education, 4(1), 17-29.

Bates, T. (2008). Transforming distance education through new technologies. In T. Evans, M. Haughey \& D. Murphy (Eds.), International handbook of distance education (pp. 217-236). Bingley, UK: Emerald Group Publishing Ltd.

Bates, A. W. (2000). Managing technological change: Strategies for college and university leaders. San Francisco, CA: Jossey Bass/John Wiley.

Becher, T. (1989). Academic tribes and territories: Intellectual enquiry and the culture of disciplines (2nd ed.). Buckingham, UK: SRHE and the Open University Press.

Becker, H. J. (2000). How exemplary computer-using teachers differ from other teachers: Implications for realizing the potential of computers in schools. Contemporary Issues in Technology and Teacher Education, 1(2), 274-293.

Bennett, S., Agostinho, S., Lockyer, L., \& Harper, B. (2009). Researching learning design in open, distance, and flexible learning: Investigating approaches to supporting design processes and practices. Distance Education. 30(2), 175-177. 
Blin, F. \& Munro, M. (2008). Why hasn't technology disrupted academics' teaching practices? Understanding resistance to change through the lens of activity theory. Computers \& Education, 50 , $475-490$.

Burge, E. J. \& Polec, J. (2008). Transforming learning and teaching in practice: Where change and consistency interact. In T. Evans T, M. Haughey \& D. Murphy (Eds.), International handbook of distance education (pp. 237-258). Bingley, UK: Emerald Group Publishing Ltd.

Calvert, J. (2005). Distance education at the crossroads. Distance Education, 26(2), 227-238.

Cleveland-Innes, M. F. (2010). Teaching and learning in distance education: Enter a new era. In M. F. Cleveland-Innes \& D. R.Garrison (Eds.), An introduction to distance education: Understanding teaching and learning in a new era (pp.1-10). New York: Routledge.

Collis, B. \& Moonen, J. (2008). Web 2.0 tools and processes in higher education: quality perspectives. Educational Media International, 45(2), 93-106.

Collis, B. \& van der Wende, M. (2002). Models of technology and change in higher education. An international comparative survey on the current and future use of ICT in Higher Education. Enschede, Netherlands: University of Twente.

Conole, G. (2007). An international comparison of the relationship between policy and practice in elearning. In R. Andrews \& C. Haythornthwaite (Eds.), SAGE handbook of e-learning research (pp. 286-310). London, UK : Sage Publications Ltd.

Conole, C. (2004). E-learning: The hype and the reality. Journal of Interactive Media in Education 11. Retrieved from http://jime.open.ac.uk/articles/10.5334/2004-12/

Daly, C. \& Pachler, N. (2007). Learning with others in mind. In J. Pickering, C. Daly, \& N. Pachler (Eds.), New designs for teachers' professional learning. London, UK: Institute of Education.

Daniel, S. J., Kanwar, A., \& Uvalic-Trumbic, S. (2009, March-April). Breaking higher education's iron triangle: Access, cost, and quality. Change (March-April). Retrieved from http://www.changemag.org/archives/back\%20issues/march-april\%202009/full-irontriangle.html

Davis, A. (2001). Athabasca University: Conversion from traditional distance education to online courses, programs and services. International Review of Research in Open and Distributed Learning, 1(2). Retrieved from http://www.irrodl.org/index.php/irrodl/article/view/19

Flor, A. G., Bandalaria, M. dP., Sibal, M. E., \& Jarmin, M.S. (2008). The changing profile of UPOU distance learners. Retrieved from https://www.researchgate.net/publication/251213187 THE CHANGING PROFILE OF DI STANCE LEARNERS

Garrison, R. (2009). Implications of online learning for the conceptual development and practice of distance education. Journal of Distance Education/Revue de L'education a Distance, 23(2), 93-104. 
Garrison, R. (2000). Theoretical challenges for distance education in the $21^{\text {st }}$ century: A shift from structural to transactional issues. International Review of Research in Open and Distributed Learning, 1(1). Retrieved from http://www.irrodl.org/index.php/irrodl/article/view/2/22

Hardy, I. (2008). The impact of policy upon practice: An Australian study of teachers' professional development. Teacher Development, 12(2), 103-114.

Harling, K. (2002). An Overview of Case Study. Retrieved from http://www.farmfoundation.org/news/articlefiles/1028-1 harling.pdf

Haughey, M. (2010). Teaching and learning in distance education before the digital age. In ClevelandInnes, MF \& Garrison, DR (Eds.). An Introduction to Distance Education. Understanding Teaching and Learning in a New Era. New York: Routledge.

Haughey, M., Evans, T., \& Murphy, D. (2008). Introduction: From correspondence to virtual learning environments. In T. Evans, M. Haughey, \& D. Murphy (Eds.), International handbook of distance education (pp. 1-24). Bingley, UK: Emerald Group Publishing Ltd.

Hedberg, J. G. (2006). E-learning futures? Speculations for a time yet to come. Studies in Continuing Education, 28(2), 171-183.

Hughes, J. (2004). Technology learning principles for preservice and in-service teacher education. Contemporary Issues in Technology and Teacher Education, 4(3), 345-362.

Jacobsen, M., Clifford, P., \& Friesen, S. (2002). Preparing teachers for technology integration: Creating a culture of inquiry in the context of use. Contemporary Issues in Technology and Teacher Education, 2(3), 363-388.

Jara, M. \& Fitri, M. (2007). Pedagogical templates for e-learning. London: Institute of Education. Retrieved from http://core.ac.uk/download/files/52/82439.pdf

John, P. D. (2005). The sacred and the profane: Subject sub-culture, pedagogical practice and teachers' perceptions of the classroom uses of ICT. Educational Review, 57(4), 471- 490.

John, P. D. \& La Velle, L. (2004). Devices and desires: Subject subcultures, pedagogic identity and the challenge of information communication technology. Technology, Pedagogy and Education 13(3), 307-326.

Kanuka, H. \& Brooks, C. (2010). Distance education in a post-Fordist time: Negotiating the difference. In M.F. Cleveland-Innes \& D. R. Garrison (Eds.), An introduction to distance education: Understanding teaching and learning in a new era (pp. 69-90). New York: Routledge.

Kirkwood, A. (2009). E-learning: you don't always get what you hope for. Technology, Pedagogy and Education 18(2), 107-121.

Kirkwood, A. \& Price, L. (2006). Adaptation for a changing environment: Developing learning and teaching with information and communication technologies. International Review of Re- 
search in Open and Distributed Learning 7(2). Retrieved from http://www.irrodl.org/index.php/irrodl/article/view/294/614

Laurillard, D. (2011). Supporting teacher development of competencies in the use of learning technologies. In Proceedings of IITE 2010: Policy, Open Educational Resources and Partnership. Moscow: UNESCO Institute of Information Technologies in Education.

Laurillard, D. (2008). Technology enhanced learning as a tool for pedagogical innovation. Journal of Philosophy of Education, 42(3-4), 521-533.

Markauskaite, L. \& Goodyear, P. (2009). Designing for complex ICT-based learning: Understanding teacher thinking to help improve educational design. Paper presented at the $26^{\text {th }}$ Annual Conference of the Australasian Society for Computers in Learning in Tertiary Education (ASCILITE), Auckland, Australia.

Mason, R. (1998). Models of online courses. ALN Magazine, 2(2). Retrieved from http://www.networkedlearningconference.org.uk/past/nlc1998/Proceedings/Mason 1.721.80.pdf

Masterman, L. \& Vogel, M. (2007). Practices and process of design for learning. In Beetham, H. \& Sharpe, R. (Eds.), Rethinking pedagogy for a digital age (pp. 52-63). London: Routledge.

Mishra, P. \& Koehler, M. (2006). Technological pedagogical content knowledge: A new framework for teacher knowledge. Teachers College Record, 108(6), 1017-1054.

Naidu, S. (2007). Instructional designs for optimal learning. In M. G. Moore (Ed.), Handbook of distance education (2nd ed; pp. 247-258). New Jersey: Lawrence Erlbaum Associates, Publishers.

Natriello, G. (2005). Modest changes, revolutionary possibilities: Distance learning and the future of education. Teachers College Record, 107(8), 1885-1904.

Otero, V., Peressini, D., Meymaris, K. A., Ford, P., Garvin, T., Harlow, D., Reidel, M., Waite, B., \& Mears, C. (2005). Integrating technology into teacher education: A critical framework for implementing reform. Journal of Teacher Education, 56(1), 8-23.

Pachler, N. \& Daly, C. (2011). Key Issues in e-learning research and practice. London, UK: Continuum.

Pearson, M. \& Naylor, S. (2006). Changing contexts: Teacher professional development and ICT pedagogy. Education and Information Technologies, 11(3-4), 283-291.

Price, S. \& Oliver, M. (2007). A Framework for conceptualising the impact of technology on teaching and learning. Educational Technology \& Society, 10(1), 16-27.

Power, M. (2007). From distance education to e-learning: A multiple case study of instructional design problems. E-Learning, 4(1), 64-78. 
Power, M. \& Gould-Morven, A. (2011). Head of gold, feet of clay: The online learning paradox. International Review of Research in Open and Distributed Learning, 12(2), 19-39. Retrieved from http://www.irrodl.org/index.php/irrodl/article/view/916/1785

Robson, C. (2002). Real world research (2 ${ }^{\text {nd }}$ ed.). Oxford: Blackwell Publishing.

Russell, M., Bebell, D., O’Dwyer, L., \& O’Connor, K. (2003). Examining teacher technology use: Implications for preservice and inservice teacher preparation. Journal of Teacher Education, 54(4), 297-310.

Sandholtz, J., Ringstaff C., \& Dwyer, D. (1997). Teaching with technology: Creating student-centered classrooms. New York, NY: Teachers College, Columbia University.

Sangra, A. (2006). Universitat Oberta de Catalunya (UOC), Spain: A newly created institution. In S. D’Antoni (Ed.), The virtual university: Models and messages; Lessons from case studies. Paris, France: UNESCO publishing. Retrieved from http://www.unesco.org/iiep/virtualuniversity/home.php\#catalunya

Sharpe, R., Benfield, G., \& Francis, R. (2006). Implementing a university e-learning strategy: levers for change within academic schools. ALT-J, 14(2), 135-151.

Siemens, G. (2007). Networks, Ecologies and Curatorial Teaching. Retrieved from http://www.downes.ca/cgi-bin/page.cgi?post=41484

Stake, R. E. (1995). The art of case study research. Thousand Oaks, CA: Sage.

Swan, K. (2010). Teaching and learning in post-industrial distance education. In Cleveland-Innes, M. F. \& D. R. Garrison (Eds.), An introduction to distance education: Understanding teaching and learning in a new era (pp. 108-134). New York: Routledge.

Tait, A. (2010). Foreword. In M. F. Cleveland-Innes \& D.R. Garrison (Eds.), An introduction to distance education: Understanding teaching and learning in a new era (pp. ix-xi). New York: Routledge.

Taylor, J. C. (2001). Fifth generation distance education. e-Journal of Instructional Science and Technology (e-JIST) 4(1): 1-14.

\section{Athabasca}

University

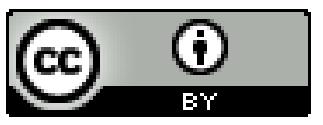

